\title{
Chapter 6: Of What Is "Ricœur" the Name? Or, Philosophising at the Edge
}

\section{What's in a Name?}

In 2007, Alain Badiou published a little book with the title De quoi Sarkozy est-il le nom? - Of what is "Sarkozy" the name?' ${ }^{1}$ The delightful rhetorical trick of this wording confronts the reader with a choice: either you respond with a lame analytical truth: "Sarkozy is the name of... Sarkozy", or you take up the challenge of looking for something else, something further and more significant, of which the person, Nicolas, is only a figure-head, the bearer of the name.

In this chapter I ask in a similar way: of what is "Ricœur" the name? Someone who has in mind Ricœur's later hermeneutics of the self may object that this is not a very Ricœurian question. After all, Oneself as Another teaches us how not to ask the question "what kind of thing a human being is," but "who a person is". However, my concern here is not the self-attestation or identification of one specific individual, Paul, but rather the significance of his work. My question is thus in agreement with the spirit of his earlier textual hermeneutics. I want to explore what he called "la chose du texte", the thing of the text, that which the text is about, and for which the name "Ricœur" is the simplest metonymic reference. What then are we speaking about, when we speak about Ricœur? To which concerns does the body of work called "Ricœur" direct our attention?

In responding to these questions, I do not attempt to provide a synoptic view of Ricœur's entire work. I rather attempt to increase the conflict of interpretations about his work by examining a set of things of which Ricœur is the name, one set of concerns that can be traced in most of his work.

But this question itself is posed by someone, who writes from somewhere, with a part of his life history behind him and his heart full of questions and worries. I confess, then, that this chapter is also a small part of my own attempt to think through life at the social "edge"2: living in a country brought to the brink,

1 Alain Badiou, De quoi Sarkozy est-il le nom ? (Paris: Éditions Lignes, 2007). Parts of the present chapter have been developed in my Lire Ricœur depuis la périphérie. Décolonisation, modernité, herméneutique (forthcoming). This accounts for a few overlaps of content, which will not be indicated each time.

2 I borrow the polysemic term "edge" from Johan Snyman, "Filosofie op die rand," Koers 62, no. 3 (1997): 277-306. The "edge" (rand) at which he philosophised is also the "ridge of the

Ә OpenAccess. ( 2021 Ernst Wolff, published by De Gruyter. (cc) BY-NC-ND This work is licensed under the Creative Commons Attribution-NonCommercial-NoDerivatives 4.0 License. 
to the edge, of civil war by totalitarian violence, the contemporary omnipresent threat of outbursts of violence, people living on the edge of unbearable trauma through exploitation and poverty, etc. ${ }^{3}$ (aspects of which are dealt with more directly in Chapters 7 and 8). But I also reflect on the position of the philosopher as somebody who stands far enough from the edge of action and events to be able to witness them - which also involves being, like other witnesses, somehow traumatised by what one is a witness to - all the while realizing the unspeakable good fortune of escaping the worst trauma oneself.

I think Ricœur found himself in a similar situation shortly after the Second World War. Confronted with recently published articles on the fate of colonized peoples, Ricœur wrote a short reflection entitled "The Colonial Question" (1947)..$^{4}$ It is an indignant outcry against the "edge" of inhumane life at which the colonized are left to languish; it is written in the awareness of his philosophising in response to this "edge". The influence of this concern reaches deep into the course of Ricœur's intellectual life, as I intend to show.

\section{3 "The Colonial Question"}

Ricœur's declared intention in this essay is to clarify, and henceforth to awaken every day, the responsibility of a non-expert in respect of the colonies. Although Ricœur writes here explicitly as a Christian and also for a Christian readership, ${ }^{5}$ he declares that the responsibility he has in mind is based on one's citizenship (in this case his French citizenship) and a lack of expertise does not relieve one of this responsibility. In fact, the feeling of responsibility emerges from the plight of the colonized:

white waters" (Witwatersrand) - the rich and tragic mining region in South Africa where we both grew up.

3 Recently, I have given an account of this history in Ernst Wolff, Mongameli Mabona. His life and work (Leuven: Leuven University Press, 2020).

4 Paul Ricœur, "La question coloniale," Réforme 3, no. 131 (20 September, 1947). I have prepared a re-edition of this article for the Fonds Ricœur, which is available at https://bibnum.explore.psl. eu/s/psl/ark:/18469/1z0z0\#?c=\&m=\&s=\&cv=, last accessed 5 February 2021. The following references are to this edition and the translations are my own.

5 But later he is more specific: "At least, these principles have the virtue of being half way between belief [foi] and politics; which is morality itself, incapable of inspiring as a belief [foi] and lacking all the technical competence required by politics." Ricœur, "La question coloniale," 4. However, one may ponder whether "foi" should here be translated as "belief" in a religious or non-religious sense, or as "faith". 
...their claim shatters me, when it turns against us the moving themes of national liberation that our struggle brought against Nazism. I'm afraid I may be a Nazi without knowing it. I hear those Germans protesting lamentably when we tell them about Auschwitz: 'We didn't know'. And we condemn them victoriously: 'Your fault is that you didn't know'. I do not know much about the French oppression in the colonies and I fear that my fault is, mainly, the fault of omission to get myself informed. ${ }^{6}$

What perspective does Ricœur offer his readers, then, on the colonial question? He advances five principles:

1. As seen from his perspective in 1947 , the only remaining legitimate objective of the entire colonial project is to bring an end to colonization and to guarantee the liberty of the indigenous populations.

2. France, and similarly the other colonial powers, have to recognize the unilateral violence of the colonizing act: "The use of violence by peoples who aspire to freedom does not increase our good right: the colonial enterprise is contaminated/invalidated [viciée] from the beginning by cunning and violence. [...] as the occupying force we have from the beginning an indelible priority in violence."

3. Ricœur declares that "[t]he trap of the colonial spirit is racism; the basis of the right of indigenous peoples is universalism." ${ }^{8}$ This means that the anticolonial protesters are more "French" than the inheritors of the "Universal declaration of the rights of man and of the citizen".

4. With his typical taste for paradox, Ricœur observes that "[t]he frantic and often premature thirst for freedom that drives separatist movements is the same passion that is at the origin of our history of 1789 and Valmy, of 1848 and June 1940, it is of no use to say that this thirst is frantic and premature". ${ }^{9}$ Even a supposedly immature drive for liberty always normatively outweighs the imagined virtue of paternalism. That such a quest for national liberty may lead to disastrous consequences may be read in the pages of European history (cf. World War I). Europeans knew before the other peoples how to fire their desire for liberty to the point where nationalism boils

6 Ricœur, "La question coloniale," 2. In 1990, he still writes: “The idea of culpable negligence is of great importance in this type of debate, as has been resoundingly echoed by the tragic events of World War II.” Paul Ricœur, Soi-même comme un autre (Paris: Seuil, 1990), 339n4 / Oneself as Another, transl. Kathleen Blamey (Chicago, IL and London: University of Chicago Press, 1992), $293 n 89$.

7 Ricœur, "La question coloniale," 3.

8 Ricœur, "La question coloniale," 3.

9 Ricœur, "La question coloniale," 3. Ricœur's article was published on the day of commemoration of the Battle of Valmy (20 September 1792). 
over, with catastrophic consequences. However, the problem here is that people did not sufficiently relativise the importance of their nation with reference to the whole of humanity; the problem is not the desire for liberty itself. Hence Ricœur's generalization - "[t]hey are right to do as we did, to want to be free ahead of schedule; they are wrong, as we were, to want to take this unnecessary detour through the nation state"10. As Ricœur states in his concluding paragraph, first, all people have to be liberated, then, together, all can fight as free people against the danger of nationalism.

5. But one might object that movements calling for independence (Ricœur calls them "mouvements séparatists"11) represent only a minority of the population. Still, Ricœur is willing to give these movements the benefit of the doubt, because they articulate the first "awareness" (prise de conscience ${ }^{12}$ ) of the normative dimension of the problem. Here one should take note of the decisive significance of the category "prise de conscience" for good political action in Ricœur's early philosophy.

Ricœur's essay is short, but its critique of the colonial enterprise is carefully argued, nuanced and unequivocal. In subsequent years, he never returned to the justification of this principled anticolonial stance. Rather, henceforth, it seems that he thought the injustice of the colonies and the need for decolonization had been sufficiently dealt with to require mere referencing. ${ }^{13}$ At the same time, it would be incorrect to think that his essay is like a fireworks display spectacular, but quickly gone. On the contrary, one may trace two lines of continued reflection on colonization/decolonization in Ricœur's work from this point on: the first is his political view on the post-colonial world order (§4); the second is a more philosophical and cultural critical reflection on decolonization and modernity ( $(5)$. If we want to understand what the name "Ricœur" stands for, we need to have a look at the coordination between these two lines of thought.

10 Ricœur, "La question coloniale," 4.

11 Ricœur, "La question coloniale," 4.

12 Ricœur, "La question coloniale," 4.

13 This does not imply that there is nothing to elaborate on, but Ricœur seems to be sufficiently convinced, and could subsequently also count on sufficient consensus, to move on to dealing with other problems, cf. "examples on which there is precisely a consensus: we do not tolerate racism, anti-Semitism, apartheid or, in another area, the sexual exploitation of children for commercial pornography.” Paul Ricœur, Lectures 1. Autour du politique (Paris: Seuil, 1991), 306. 


\section{Ricœur's Anticipation of Global Politics after Independence}

A snapshot on Ricœur's changing political views is "True and False Peace" (1955). ${ }^{14}$ It was published a few months after the beginning of the Algerian war of independence and seven years before its end. It was presented as a paper a few days after the Bandung Afro-Asian conference, which he welcomed as being of great historico-political significance. He devotes several pages of this paper to decolonization.

Interestingly, there is no justification of an anti-colonial stance in this article. Ricœur already writes from a post-independence perspective. His reflection on the burning geopolitical issues of his day is focused on the following paradox: two opposing visions of the economic organisation of human societies - capitalist and communist - hold the same destructive potential - in fact, so massively destructive that outright victory of any one side over the other is likely to entail the destruction of the conditions of life for all the winners too. Since self-destruction is no option, the only remaining option is peace. But will it be a true or a false peace? That is Ricœur's question. False peace is the construction of a balance between a liberal and a communist bloc - presented through Manichean ideological simplification as absolute opposites. A true peace would reveal the underlying similarities and complexities of the geopolitical order.

Decolonization is a central component of Ricœur's understanding of a global political order and the possibility of peace. What the ideology of the "two big blocs” hides was revealed at Bandung, namely the reality of a complex network of international stakeholders. But Ricœur remains perplexed about the means by which these new role-players could assume their rightful position in international politics (cf. Principle 4 of “The colonial question"). Finally, he concedes these nationalisms may play a progressive political role, may be a legitimate means by which to attain political autonomy, on three conditions:

- if, as liberation movements, they articulate the "awareness" (prise de conscience) of foreign oppression,

- if, as attempts to re-anchor people in history and land, they signal a return to "popular and local culture", and

- if they can realize people's aspiration towards modernisation. ${ }^{15}$

14 Paul Ricœur, "Vraie et fausse paix" (1955), as republished in Autres Temps 76-77 (2003): 51-65.

15 See Ricœur, "Vraie et fausse paix," 58. 
Schematically, then, decolonization unleashes the plurality of cultures; nationalisms give geopolitical force to this plurality and in this way undermine the simplistic geopolitical ideology of there being only two opposing camps. Yet, political reality is more complex: small countries tend to align themselves with big powers, even at the risk of losing some of their independence and cultural specificity. In this regard, Ricœur underscores the corrupting potential of American capitalism, but is slightly more positive about the influence of Russian and/or Chinese communism on the African continent. Such a communism is to be approved, provided that the concomitant philosophy of materialism does not smother local "cultures" or "spiritualities", but rather merges with them. ${ }^{16}$ By the way, before concluding that this is mere conservative culturalism, remember that we are standing here on the eve of African socialisms - as far as African politics is concerned, Ricœur finds himself in very good company. ${ }^{17}$

Therefore, the countries that are struggling for their independence should be assisted in attaining real independence - not a new form of dependence on one of the two blocs. Interestingly, France has a role to play in progressive decolonization (for which Ricœur, surely idealistically, thought that the Union Française provided the framework): by first assuming its own independence completely and not aligning itself with the capitalist or communist bloc, France could strengthen the hand of the newly independent states, and thus prevent them from (over-)aligning with either the communists or the capitalists, for the same reasons. Or, one may conclude that France was to help the nations literally or symbolically gathered at Bandung to remain non-aligned, so that France could align itself with them and by so doing, retain its own independence! This was, as far as Ricœur can see, the surest path to "real peace". ${ }^{18}$

16 Ricœur, "Vraie et fausse paix," 59.

17 Cf. Introduction to Saïd Bouamama, Figures de la révolution africaine. De Kenyatta à Sankara (Paris: Découverte, 2017), 5-18, and William Friedland and Carl Rosberg, African Socialism (Stanford, CA: Stanford University, 1967).

18 A similar position has been confirmed from a contemporary view on the geopolitical order by Bertrand Badie, Quand le Sud réinvente le monde. Essai sur la puissance de la faiblesse (Paris: Découverte, 2018). His point is also that the entire geopolitical order should be reviewed in light of the up-to-now insufficiently recognized significance of decolonization.

The importance of France's non-alignment is already anticipated in Paul Ricœur, "Le chrétien et la civilisation occidentale” (1946), as republished in Autres Temps 76-77, (2003): 23-36, where Ricœur advocates a positioning of France independent from Russia and America, and drawing its energy first of all from its own inventive core. For background, see François Dosse, Paul Ricœur. Les sens d'une vie (1913-2005). Edition revue et augmentée (Paris: La Découverte, 2018), especially 192-93. 
Having thus demonstrated that "Ricœur" is the name for an anti-colonialism developed into a view of strategic geopolitical alignment with the variety of decolonized states, I move on to the second line of development.

\title{
5 Ricœur's View on the Philosophical and Cultural Critical Consequences of Decolonization
}

On the one hand, Ricœur was deep under the impression of the epochal change brought about by decolonization; on the other, this new reality was in the first place not to be regarded as a source of conflict or struggle (a "clash of civilizations") but as the emergence of the richness of human existence. A last citation from "True and False Peace" brings together all of these themes:

\begin{abstract}
the Bandung conference [the rallying point and symbol for decolonization - EW] reminds us that the facts are stubborn and that the world will not let itself be ordered into two battle lines. There is latent, potential diversity that seeks to express itself. Modern reality, in its human depth, is not dualistic, but really pluralistic. So, when we speak of French independence, we are alone only in appearance and at first glance, that glance which is sensitive only to the strategic device of the camps [capitalist and communist - EW] and not to the human richness of our globe. ${ }^{19}$
\end{abstract}

We gain a better view on this globalized plurality by turning to the 1961 essay: "Universal Civilization and National Cultures". ${ }^{20}$ It captures Ricœur's diagnosis of the post-independence world. The same diagnosis applies, albeit in two distinct ways, to what he calls the "industrialized" and the "underdeveloped" nations of the earth.

19 Ricœur, "Vraie et fausse paix," 66. The significance of decolonization for a proper, modern European self-understanding is echoed three decades later in Ricœur's reflection in Time and Narrative: "Eurocentrism died with the political suicide of Europe in the First World War, with the ideological rending produced by the October Revolution, and with the withdrawal of Europe from the world scene, along with the fact of decolonization and the unequal - and probably antagonistic - development that opposes the industrialized nations to the rest of the world", Paul Ricœur, Temps et récit 3. Le temps raconté (Paris: Seuil, 1985), 369-70 / Time and narrative 3. Transl. Kathleen Blamey and David Pellauer, (Chicago, IL: University of Chicago Press, 1988), 204.

20 Paul Ricœur, "Civilisation universelle et cultures nationales," in Histoire et vérité (Paris: Seuil, 1967), 322-38 (cf. "mondialisation”, 324) / "Universal Civilization and National Cultures," in History and Truth (Evanston, IL: Northwestern University Press, 1965), 271-84. 
Everybody witnessed the rise of a "single world civilization", ${ }^{21}$ which is located first and originally in the rise of the scientific spirit and then its consequences in the spheres of technology, rationally organized politics and economics, and, finally, aspects of a global everyday life culture (clothing, information, consumption, etc.). ${ }^{22}$ On Ricœur's reading, the fact that the industrialized nations have been a steady source of this putative "universal civilization" does not mean that Western culture really is universal civilization. One may have preferred to see Ricœur explore the hegemonic rise of this global civilization, however, the significant point he is making is a different one: whereas this universal civilization unifies and homogenizes humanity, ${ }^{23}$ the new condition of globalization consists of leaving the plurality of human cultures juxtaposed on the same level: without any normative priority, without any higher order for arbitration. And all peoples face the same tension between the progress of universal civilization and their own cultural heritage.

On the one hand, Ricœur appreciates in universal civilization the unheard-of progress in the form of a self-awareness of humanity, (the possibility of) access to basic goods, and rights and education on a scale previously unknown. On the other hand, he is concerned about the destruction of the cultural treasures of humanity's diverse traditions. Why? Because these traditions represent the creative core of humanity (elsewhere he refers to them as the "raison d'être" of a people), the destruction of which signals the flooding in of a pervasive nihilism. ${ }^{24} \mathrm{How}$ ever, the affirmation of the cultural treasures of humanity is not without its own difficulties, exactly because globalization leaves us with no hierarchy and only the juxtaposition of "others"; we, whoever that may be, are only one other among all the others.

In a nutshell, the current predicament is twofold: first, the plurality of cultures is not yet negotiated and, second, the articulation of the relation between an expanding universal civilization and the kaleidoscope of cultural heritages

21 Ricœur, “Civilisation universelle...,” 322 / “Universal Civilization...,” 271.

22 There are reasons to question the order of originality in Ricœur's presentation, but even if one does not follow him in this schematic chronology of the formation of "universal civilization", this does not affect the core of the problem that he articulates in this essay.

23 Likewise, one could question how homogenized and unified modern global culture is, but Ricœur's point is simply that it is so sufficiently to contrast to national cultures, as he subsequently does. Cf. Krishan Kumar, From Post-industrial to Post-modern Society. New Theories of the Contemporary World. 2nd ed. (Malden, MA, Oxford, and Carlton: Blackwell, 2005).

24 In an uncommonly apocalyptic tone, Ricœur claims that, taken to its severest extremes, this nihilism would be as destructive for humanity as an atomic war, cf. Ricœur, "Civilisation universelle...," 331 / "Universal Civilization...," 278. 
has not yet been figured out. Ricœur points in the direction where solutions might be found:

- for industrialized/Western countries, openness to unfamiliar cultural spheres $^{25}$

- for developing nations, the difficult negotiation between progress and tradition, ${ }^{26}$ and

- for both, a dialogue of cultures.

Now, before one makes of this a facile "happy ending”, listen to how Ricœur senses the magnitude of the task ahead:

No one can say what will become of our civilization when it will have truly met other civilizations other than through the shock of conquest and domination [that is, colonization and war - EW]. But we must admit that this encounter has not yet taken place at the level of a real dialogue. That is why we are in a kind of interlude, an interregnum, where we can no longer practice the dogmatism of the one and only truth and where we are not yet capable of overcoming the scepticism into which we have entered: we are in a tunnel, at the twilight of dogmatism, at the threshold of true dialogues." ${ }^{27}$

I would say, we are historically at an "edge".

One can hardly overestimate the importance of these conclusions: they articulate Ricœur's cultural critical assessment of the world at that time, and as far as I

25 Ricœur, “Civilisation universelle...,” 337 / "Universal Civilization...,” 283.

26 Cf. Ricœur, “Civilisation universelle...,” 329 / “Universal Civilization...,” 277: "Thus we come to the crucial problem confronting nations just rising from underdevelopment. ln order to get onto the road toward modernization, is it necessary to jettison the old cultural past which has been the raison d'être of a nation? The problem often comes up in the form of a dilemma or a vicious circle. The fight against colonial powers and the struggles for liberation were, to be sure, only carried through by laying claim to a separate personality; for these struggles were not only incited by economic exploitation but more fundamentally by the substitution of personality that the colonial era had given rise to. Hence, it was first necessary to unearth a country's profound personality and to replant it in its past in order to nurture national revendication. Whence the paradox: on the one hand, it has to root itself in the soil of its past, forge a national spirit, and unfurl this spiritual and cultural revendication before the colonialist's personality. But in order to take part in modern civilization, it is necessary at the same time to take part in scientific, technical, and political rationality, something which very often requires the pure and simple abandon of a whole cultural past. lt is a fact: every culture cannot sustain and absorb the shock of modern civilization. There is the paradox: how to become modern and to return to sources; how to revive an old, dormant civilization and take part in universal civilization."

27 Ricœur, “Civilisation universelle...,” 338 / "Universal Civilization...,” 283-84. 
can see, this is the question that his hermeneutics is tasked to respond. This is a major - if not the primary - motivation for Ricœur's hermeneutics.

To support this claim, let us turn to Ricœur's Symbolism of Evil, which appeared only one year earlier in 1960. This is usually held to be Ricœur's first important work in hermeneutics. The conclusion of this book famously outlines Ricœur's hermeneutics of symbols. However, to measure how enormous this task is, we have to turn to the introduction of the same book. There Ricœur argues that the hermeneuticist - in this case, the Western inheritor of the Greek philosophical tradition - is, like everybody else, surrounded by a sea of symbols. But, again like everybody else, our hermeneuticist is oriented. "Orientation” accords a de facto privilege to certain cultures; in Ricœur's case the Greek and Hebraic traditions. But this means equally that in the hermeneutic view, de jure, symbols from all cultural spheres are matters for study. But how can one practically affirm both the significance of all "other" cultures (not just pay lip-service to their importance) and the orientation of hermeneutics (without implicitly adopting a view from nowhere)? Ricœur makes two suggestions:

1. The Western hermeneuticist may

- elucidate the sedimentation of our cultural memory [by using] documents relating to civilizations that do not belong to this [Greco-Hebraic] memory - African, Australian, Asian, etc. - and that are very often [our] contemporary civilizations ; [but] the objective similarity that ethnology discovers between them and our own past allows us to use the knowledge of these civilizations to diagnose our own abolished or forgotten past. $^{28}$

- This seems to indicate that something could be gained by comparing a genealogy of our self-understanding with even the remotest cultural traditions.

2. Or again, one could acknowledge that the Western orientation in hermeneutics does not correspond with the concrete universal. It cannot in fact do so, since it lacks the required input from other cultures. This implies that although the contingency of thinking from a specific history cannot be over-

28 Paul Ricœur, La symbolique du mal [1960] in Philosophie de la volonté 2. Finitude et culpabilité (Paris: Editions Points, 2009), 224 (own translation, modification to fit main text) / The Symbolism of Evil, trans. Emerson Buchanan (Boston, MA: Beacon, 1969), 21.

Is there a hierarchy implied in this passage between the cultures from Africa, Australia and (the rest of) Asia vs India and China? The letter of the text contradicts this, and the impression may be due simply to the selectiveness of the examples given. However, Ricœur passes over the question of contemporary comparisons - this is addressed in the following point. 
come, progressively more views can be incorporated and thus the Western view can be broadened. ${ }^{29}$

It has to be conceded that such a confrontation and/or negotiation between cultures has thus far remained the passion of isolated researchers. To change our memory - the tradition of our thought and culture - great works are needed that will re-create our memory by incorporating the (thereafter former) other into it.

Just as in "Universal Civilization...”, Ricœur acknowledges that such a massive encounter between cultures has not yet taken place. However, when such encounters will take place, it is sure to be a world historical moment - Ricœur calls it a moment of "foundation" and "re-creation"30 - in the Western framework, comparable only with the encounter of the Greek and Hebraic traditions. What Ricœur does not say in Symbolism of Evil, but in "Universal Civilization..." is that decolonization has pushed us to the point, to the edge, where we can no longer avoid this confrontation with the cultural other (other than by new forms of violence). Allow me to exaggerate my conclusion to make this point clear: "Ricoeur" is the name for hermeneutics as motivated by the question: how are we to prepare ourselves for the encounter with others, now that the end of the colonies has revealed the modern world to be a relativistic juxtaposition of cultures?

\subsection{Interim Conclusion: Disillusioned Modernity and the Task of Hermeneutics}

I would like to make a few concluding remarks to round off this reconstruction of Ricœur's motivation for hermeneutics.

First, if we were to project Ricœur's later insights on the post-colonial dispensation back onto his initial critique of the colonies, we may conclude that the colonial project was a double catastrophe. On the one hand, it was a unilateral act of violence perpetrated against colonized peoples; on the other hand, it was catastrophic as a futile gesture by which the people in whose midst modernity emerged attempted to hide (from themselves, as from others) the real condition of modernity, namely globalized cultural plurality. Liberating the Western mind of this colonial mind-set is thus a logical extension of the initial task of bringing an end to the colonial project. We may call this the negative task of hermeneutics.

29 Cf. Ricœur, La symbolique du mal, 226-27 / The Symbolism of Evil, 22-23.

30 Ricœur, La symbolique du mal, 226 / The Symbolism of Evil, 23. 
Second, Ricœur's understanding of hermeneutics opens the door to increasing inclusion of the cultural other. This is part of the positive task of hermeneutics. Therefore, looking back at these texts of the first two post-World War II decades and these two conclusions, one has to infer that Ricœur's return to cultural traditions could be construed as a conservative dream of a revival only at the expense of considerable violence to his political concerns and his diagnosis of the contemporary era. Ricœur's point is not to flee the present by withdrawing to our respective paradises of cultural particularism. It is rather a plea to face the tremendous challenge - partially created by modernity, then revealed in the events of decolonization - of one humanity facing a number of problems under a regime lacking any a priori hierarchy between traditions. Summarised in a simple formula: post-coloniality as an essential trait of modernity is the frame from which Ricœur's hermeneutics develops. Or again: "Ricœur" is the name for a hermeneutics of cultural traditions under the conditions of disillusioned modernity.

However, third, in Symbolism of Evil at least, the confrontation with the cultural other takes place while the other is implicitly being represented by the Western hermeneuticist in an attempt to work through and appropriate this otherness. As a model of appropriation, this is probably inevitable, but it still raises the question of how far this openness to the cultural other can be taken by a single hermeneuticist. In response to this question, I need to refer to two components of Ricœur's work, to demonstrate that he was aware of this problem and worked on it. We could cite, on the one hand, his contribution to the work of non-Western philosophers, for example, in the numerous prefaces written to books. ${ }^{31}$ On the other hand we should note his published contributions to intercultural philosophy in the framework of his involvement in UNESCO. ${ }^{32}$

31 In Frans Vansina (and Pieter Vandecasteele), Paul Ricœur. Bibliographie primaire et secondaire. Primary and secondary bibliography. 1935-2008 (Leuven: Peeters, 2008) see references to René Habachi, Nabil Mouannes, Kha Sae-Yang, Bechara Sargi, Beatriz Couch and Humberto Giannini. See also the tribute to Ricœur in the volume Présence de Paul Ricœur (Tunis: Beït al-Hikma, 2003) prepared by the Académie Tunisienne de sciences, des lettres et des arts. However, given the strong Western philosophical nature of these books, this point should not be exaggerated.

32 Among these, the most important are his introductions to Cultures and Time (Paris: UNESCO, 1976), 13-33 and to Time and the Philosophies (Paris: UNESCO, 1977), 13-30. Also noteworthy are his "Introduction" to Philosophical Foundations of Human Rights (Paris: UNESCO, 1986), 9-29, and "Projet universel et multiplicités des héritages," in Où vont les valeurs? Entretiens de XXIe siècle II [2001], ed. Jérôme Bindé (Paris: Unesco - Albin Michel, 2004), 75-80. My point is not to hail these works as blueprints for intercultural philosophy (the precise nature of the 
These two points amount at least to the suggestion that Ricœur concedes that his own project of hermeneutics requires completion by the cultural other. The very constitution of the postcolonial predicament to which hermeneutics is a response would require that the others' response to the same disillusioned modernity has to be faced by Westerners.

Let me unpack the implications of this point. The postcolonial predicament is that the very cultural life-force from which people act threatens us with nihilism and/or geopolitical conflict. In response to this ambiguity of cultural plurality, hermeneutics is charged with understanding ourselves in this situation. We, whoever we may be, come from a cultural background. However, we are also people living with others in this plurality. More generally, we may claim that if we want to understand ourselves (as people of postcolonial modernity) we can do so only if we also listen to others trying to understand themselves (and they listen to us doing that too). Such engagement with the other does not suspend our contingency, but helps in dealing with the relativism. Hence, if we ask how others deal with Ricœur's question of the postcolonial predicament or disillusioned modernity, this is not a simple nicety, a flight of exoticism, or a fad called "post-colonial studies" - it is essential to confronting the stated predicament. In this regard, it is not trivial to name (as a first step) the significant reception of Ricœur in post-independence Africa. ${ }^{33}$ The cumulative message is clear: there is something in Ricœur that helps us, as Africans, to understand our situation even if we are situated quite differently in the global order. "Ricour" is the name for something that is also our concern.

But even this point remains insufficient as long as we have not listened to these authors, making their claims on their own terms. Let us explore this avenue, by turning to at least one example.

strengths and weaknesses of these works needs to be studied carefully), but simply to cite the massive evidence of Ricœur's openness towards the philosophies of the whole world.

33 Cf. especially Theophilus Okere, African Philosophy: A Historico-Hermeneutical Investigation of the Conditions of its Possibility (Lanham, MD: University Press of America, 1983), Nkombe Oleko, Métaphore et métonymie dans les symboles parémiologiques. L'intersubjectivité dans les "Proverbes Tetela" (Kinshasa, Faculté de théologie catholique, [1975] 1979) and Okolo Okonda, Tradition et destin. Essai sur la philosophie herméneutique de P. Ricœur, M. Heidegger, et H. G. Gadamer (Lubumbashi: Université Nationale du Zaïre: 1978-1979). More recently, Raphael Okechukwu Madu, African Symbols, Proverbs and Myths. The Hermeneutics of Destiny (New York, NY: Peter Lang, 1992) and Vincent Davy Kacou oi Kacou's trilogy: Penser l'Afrique avec Ricœur (Paris: L'Harmattan, 2013), Paul Ricour. Le cogito blessé et sa réception africaine (Paris: L'Harmattan, 2014), and L'herméneutique du soi chez Paul Ricœur. Prolégomènes à une éthique de la reconstruction de l'Afrique (Paris: Mon Petit Éditeur, 2014). 


\section{Okolo - "Praxis Triggers the Hermeneutical Process and Gives it an Orientation"}

In the remainder of this chapter I engage with the difficult question of how such a dialogue may be constituted. To be precise, we are not thinking of just any exchange between any two random people. If Ricœur's own project of hermeneutics requires completion from the cultural other, and if studying how others deal with disillusioned modernity is essential to our own dealing with this predicament, then we have to show how a dialogue on these terms and with a view to this problem could possibly be set out. My concern here is not the outcome of such a debate, but the structure of it (in as far as it can take place in philosophical practice). I attempt to clarify this issue with the help of Okolo Okonda, ${ }^{34}$ one of the younger, major role-players of what Tshiamalenga Ntumba and others have named "the Kinshasa school" ${ }^{35}$ Let us look for an entry to Okolo's thought via the theme with which he chose to open his book Pour une philosophie de la culture et du développement [Towards a Philosophy of Culture and Development] $(1986)^{36}$, namely proverbs. What could fit better with Ricœur's hermeneutics than an examination of another kind of linguistic expression, alongside symbols, metaphors, and narratives? The transition from Ricœur to Okolo seems to be a natural one. Yet, by this choice of theme, Okolo implicitly identifies his situation in world cultures, a situation that can hardly be further away from that of Ricœur. Let us have a look at this.

Ricœur famously liked to think of philosophical work as having a continuous dialogue with the authors of the past and the present through their books, lying open on his desk; ${ }^{37}$ this is how Ricœur thought and wrote. Now, imagine a world where you can enter only if you close all those books; imagine a world where human intelligence circulates independently from books, because...

34 Following Zairian/Congolese patronymic practice, the philosopher is called Okolo.

35 Tshiamalenga Ntumba, "Die Philosophie in der aktuellen Situation Afrikas," Zeitschrift für philosophische Forschung 33, no. 3 (July - September, 1979): 428-43, here 433. For a historical perspective on the position of Okolo's early work in the panorama of African philosophies, see A. J. Smet, Histoire de la philosophie africaine contemporaine. Courants et problèmes (Kinshasa: Limete, 1980), 232-33.

I am currently finalizing a volume on African philosophical hermeneutics in which a whole chapter will be devoted to Okolo. The very thin slice of his work presented here is motivated by the specific problem stated in this paragraph.

36 Okolo Okonda, Pour une philosophie de la culture et du développement. Recherches d'herméneutique et de praxis africaines (Kinshasa: Presses Universitaire du Zaïre, 1986).

37 "Paul Ricœur: un parcours philosophique.” Interview with F. Ewald, Magazine littéraire 390 (2000): $20-26$. 
there are none: no ancient philosophical texts, no Holy Scripture, no published poetry, no volumes of historiography, no printed constitution, no handbook of linguistics. Imagine an oral culture. In such a world, the extraordinary philosophical capability of Ricœur is reduced to nothing, because it simply does not belong there. ${ }^{38}$ We are in the world of the mnemosphere, the importance of which I insisted on in Chapter 1 (especially §3.2).

There was a time when many people looked upon this contrast between oral culture and the mountains of published thought in the West as suggesting that intelligence cannot circulate in such a world. Yet this is precisely the paradigmatic situation from which so many of the first post-independence African philosophers thought and, indeed, many contemporary African philosophers think. The beginnings of contemporary written African philosophy do not start with ancient documentation of the autonomous affirmation of philosophical reason - as with Greek philosophy ${ }^{39}$, but with the very existence of such a rationality being questioned by others.

A very simplified and schematic history of the emergence of written philosophy in Africa since World War II can help us to appreciate the significance of proverbs in respect of the core concern of this tradition. A "first generation" of authors strongly affirmed both that Africans were quite as gifted with reason as all other humans, and that they were philosophising long before the tragic advent of their "civilizers". These ethno-philosophers claimed to have pin-pointed African philosophy by studying the languages and oral literature of African peoples and by synthesizing their underlying metaphysical, ethical, and anthropological insights. With their languages and oral literatures, Africans safeguarded and transmitted the thought - indeed, the philosophy - of the ancestors through the troubled colonial era to our day. Therefore, when Okolo later focuses on proverbs, he is not merely investigating a kind of linguistic utterance - he is returning to the locus of debate on

- the conditions for the possibility of African philosophy,

- the defence of the rationality and thus the human dignity of African peoples, and

38 This does not mean that Ricœur was ignorant of the question of orality. See Paul Ricœur, "Philosophy," in Main Trends of Research in the Social and the Human Sciences, Part 2/2. Legal Science. Philosophy, ed. J. Havet (The Hague, Paris, New York, NY: Mouton-Unesco, 1978), 1071-1567, here 1367.

39 In the framework of this schematic presentation I do not consider the place of ancient Egyptian thought in African philosophy. On this question, see Théophile Obenga, La philosophie africaine de la période pharaonique, 2780-330 avant notre ère (Paris: L'Harmattan, 1990). 
- the attempt to subvert a presumed basis of European chauvinism (the claim of intellectual superiority), and thus continue to dismantle the heritage of colonialism, which is a major point of orientation in African politics.

So, when speaking about proverbs with Okolo, we are ideally situated for the kind of debate to which Ricœur's thought opens, but that he cannot complete by himself. It is ideal because the proverb as oral literature, depending as it does on an oral socio-cultural world, ${ }^{40}$ represents an important other vis-à-vis Ricœur's writing-dominated world; at the same time, as a significant cultural fact of many divergent peoples, proverbs are a theme around which philosophers from different traditions may gather.

But these introductory remarks are still insufficient to appreciate what an intercultural hermeneutics of linguistic utterances would mean. To appreciate the complexity of setting up such a debate in a meaningful way, we have to consider two dilemmas faced by Okolo due to his situation in African philosophy.

As a "third generation" African philosopher, he cannot simply participate in the celebration of the intelligence of traditional African culture, because the "second generation" has spoiled the party. They did so by critiquing the "first generation's" very ethnographic attribution of a "philosophy" to all Africans, without qualification, thus attributing to traditional African societies a set of universally and unanimously held ideas. Paulin Hountondji, ${ }^{41}$ a key second generation philosopher, claims that there is actually no philosophy underlying the cultures studied by first generation ethnophilosophers; the ideas they formulate are projected onto African tradition, but are in reality the invention of the philosopher. According to him, there is indeed such a thing as African philosophy, but it is to be found not directly within African traditions, but rather in the books of ethnophilosophers. This is a great and disturbing conclusion: great, because he still affirms the reality of an African philosophy; disturbing, because it amounts to making European philosophy the measure for philosophy in Africa after all (European particularity just happens to be universal). And thus the question of pre-colonial African philosophy independent of the European mind is raised again. Therefore, if Okolo wants to philosophise about proverbs as an African philosopher, he has to work his way through this critique.

His second problem is related to his philosophical practice itself. For an African philosopher, as an African philosopher, the questions of culture, heritage,

40 Cf. Chinua Achebe, Things Fall Apart (London: Penguin, [1958] 2006), 7: “Among the Igbo, the art of conversation is regarded very highly, and proverbs are the palm-oil with which words are eaten."

41 Cf. Paulin Hountondji, Sur la "philosophie africaine” (Paris: Maspéro, 1976). 
history, origin and therefore situation are of defining importance. Yet, as a person who also participates in modernity and "global civilization", Okolo practises a philosophy that is shaped by his doctoral research at a more or less western styled university, developing debates in writing (publishing in journals and books), with a view to exchanging ideas with colleagues elsewhere in the world. ${ }^{42}$ Thus, on the one hand, he should be careful not to take his own practice for granted, in such a way that he inadvertently declares the European mode of philosophising, the European agenda and concerns, to be the standard. On the other hand, he cannot pretend to be a pre-colonial African, for instance, as if his own culture is purely oral.

In short, Okolo is part of the same globalizing, homogenizing universal culture - even if he is situated quite differently in it - and he knows this to be the case. Now, how will he deal with these dilemmas? By choosing proverbs as the focal point, he can deal with all these issues at once.

What qualifies them as theme for debate? Proverbs exist first of all as a component of oral exchange. Second, they are exchanged and thus spread over space and transmitted over time. Third, proverbs have a recognizable stability. Fourth, proverbs contain ideas about a variety of aspects of life. Fifth, the second, third and fourth traits conjoin to make of proverbs a form of literature. In fact, based on these latter traits we may claim that proverbs, though oral, form text-like entities. ${ }^{43}$

Their text-likeness has made it possible for scholars to catalogue and systematise proverbs, thus allowing Okolo and his colleagues a synoptic view, in printed version, from which to launch his study. Okolo captures his own conclusions in three claims:

Claim 1: Proverbs don't think. The wisdom of proverbs cannot be systematized into a systematic whole. At least three facts can be cited in support of this claim. First, different proverbs reflect different life situations (family, profession, etc), different stages of life (youth, old age, etc.), different socio-economic conditions (poverty, wealth, etc). Second, proverbs contradict each other. Third, tradition transmits only an ideologically biased selection of proverbs, so the collection of proverbs partially reflects the interests of the powerful. ${ }^{44}$ The iconoclastic con-

42 This is what Valentin-Yves Mudimbe calls the "epistemological filiation", cf. The Invention of Africa. Gnosis, Philosophy and the Order of Knowledge (Bloomington, IN and Indianapolis, IN: Indianapolis University Press, 1988), 19, 185.

43 These five points are cited from (and is argued in more detail) in my forthcoming chapter on Okolo referred to above.

44 On this point see historian Jeffrey Peires's observation: “In oral societies even more than in literate ones, it is the victors who record the history, particularly if the losers become reconciled 
clusion that Okolo draws is that the ethnophilosophers are mistaken in considering proverbs as embodying African philosophy. Between the proverbs, there is no eloquent philosophy; there is only silence. ${ }^{45}$

Claim 2: Proverbs provoke thinking. However, Okolo finds no reason to believe that people would transmit these proverbs for ages without the corresponding contradictions striking them and stimulating their thought. Quite the contrary - and the advances in historiography of oral culture ${ }^{46}$ support him: the transformation and variations in transmission, the creation of new proverbs, the creative application of proverbs - all of these testify to proverbs' provoking thought. ${ }^{47}$ In fact, the history of oral traditions teaches us not to remain fixated on the particular proverbs, but to include them in a circuit of proverb use. Two components are inherently part of the use of proverbs: reading and "re-taking" (reprise). The more "stock-taking" part, which Okolo calls "reading", includes understanding proverbs and using them. The more creative part, Okolo which calls "re-taking", refers to all appropriations of proverbs, ranging from returning to them and resuming their use, to repairing and correcting them. ${ }^{48}$ The core of Okolo's hermeneutics consists of describing how people read and re-take proverbs with a view to their specific context of praxis.

Claim 3: Thinking from the proverb is a paradigm for all African thought. The catalogues of proverbs, amplified by the action-restoring historiography, suffice to conclude not only that the contemporary philosopher could still think from and via proverbs, but also that the colonial and precolonial ancestors already did so. Whether that thinking is to be called "philosophy" or not does not seem to concern Okolo any longer. But why would anybody return to such prov-

to their defeat." Peires, The House of Phalo: A History of the Xhosa People in the Days of their Independence (Berkeley, CA and Los Angeles, CA: California University Press, 1981), 30.

45 Following Njoh Mouelle, "wisdom is not to be sought in what each of these proverbs expresses, but rather in the interval between them; and this interval is unfortunately made of silence" (cited in Okolo, Pour une philosophie, 14).

46 Cf. Jan Vansina's pioneering work, Oral Tradition. A Study in Historical Methodology, trans. H. M. Wright (London: Routledge and Kegan Paul, [1961] 1965). But recently also Okolo Okonda and Jacques Ngangala Balade Tongamba, Introduction à l'histoire des idées dans le contexte de l'oralité. Théorie et méthode avec application sur l'Afrique traditionnelle (Louvain-la-neuve: Academia-L'Harmattan, 2018).

47 This point is made in critical debate with Nkombe, Métaphore et métonymie.

48 In other words, the creative work on tradition that Hountondji attributed to the ethnophilosphers was already part of the work of oral tradition. At the same time, ethnophilosophy missed its own point, as it were, by assuming that African philosophy was to be sought in a putative set of common convictions, and in this way missed the rational ability to engage with social contradictions (cf. Okolo, Pour une philosophie, 66). 
erbs, or rather proverb use? Certainly for the insights gained in an oral tradition, but also because proverb use serves as the paradigm for African tradition in general, in other words, as a model for thinking about reading and re-taking any aspect of tradition. Such "thinking from the tradition" is motivated in two ways. To begin with, the crisis of life in many parts of Africa requires reflection on the culture to be saved and also on all the intellectual means available to do so (for example, to unmask ideologies of development). Next, there is a need to mobilise people to confront the demands of development, and this can be done much better if engagement with these demands from the tradition allows people a culturally specific self-identification, as agents of this process. ${ }^{49}$ In Okolo's words:

The interest in going to the past is sparked by the current situation: a hermeneutical situation that is at the same time a practical situation. For us it is a question of spiritual and material survival. We feel invaded by a culture that disposes of powerful means to expand and to dominate. We are also among those who are starving and suffering from material deprivation. This situation has been going on for a long time and is still going on. [...] Praxis triggers the hermeneutical process and gives it an orientation. Hermeneutics, in turn, offers praxis a cultural self-identification, required for the ideological struggle..$^{50}$

One could rephrase in Ricœurian parlance this forceful affirmation of "thinking from the tradition" motivated by current praxis: Okolo is the name for a critique of the current socio-political conditions of life in Zaïre (the DRC), conditions shaped to a great extent by global modernity; this critique is practised knowing what the positive potential of modernity is too. But it is also the name for continued engagement with the local traditions by which people may find for themselves the terms in which they want to struggle for their freedom in this world. ${ }^{51}$

49 This affirmation of the feedback loop between hermeneutics and praxis is not meant exclusively as a general ideal for (African) hermeneutics, but reflects also Okolo's motivation for his work in hermeneutics, already in his thesis of 1979: "our hermeneutical situation is that of a reader who is searching for the identity of his/her tradition in a context of almost total dependence, who knows that our individual, national or continental struggle must join the planetary struggle for more equality and justice. This hermeneutical situation directs our present research in a particular way." Okolo, Tradition et destin, 6.

50 Okolo, Pour une philosophie, 28, 46. This echoes significantly Ricœur: "In order to confront a self other than one's own self, one must first have a self." Ricœur, "Civilisation universelle...," 337 / "Universal Civilization...," 283, but for that matter his entire hermeneutics of the capable human.

51 Since the critique of modernity does not amount to a one-sided demonization of foreign influence, and insofar as the work on tradition is (a) guided by the struggle for freedom of all citizens and (b) based on tradition as a place of debate rather than as dogma, I do not see this position echoing a Mobutuist ideology of authenticity. On this subject see the dossier "Université 


\subsection{Taking Stock: Engagement without Promises}

Let us now specify the precise nature and limits of the conclusions to be drawn from this brief excursion into Okolo's thought. Nothing more has been offered than a table set for dialogue. Nothing has been said about the outcomes of a possible debate between Ricœur and Okolo, no indication has been given of any problem solved. In fact, nothing of what has been said allows us to take for granted that such a dialogue would result in a constructive outcome. ${ }^{52}$ Rather, it has demonstrated that Ricœur's idea of completing his project with the help of the cultural other - an other thinking on his/her own terms about disillusioned modernity - is not vain.

In principle, such dialogue could - and should - be set up between a thousand other authors, but not with just anybody. There can be a meaningful exchange for the purposes outlined here, only on three conditions that are met in the debate I have set up:

1. Both authors must be aware of the mutually relativising juxtaposition of world cultures. Accepting the relativity of their own cultural background, they need to understand the difficulties of coordinating one's local culture-specific views with the increasingly globalized "universal civilization". However, referring repeatedly to people's cultural background, it was never supposed that African or Western intellectual expression necessarily thematized one's cultural background in a central way. ${ }^{53}$ Nor should one

national du Zaïre: débat sur l'authenticité revisitée" in Isidore Ndaywel è Nsiem, ed., Les années UNAZA (Université Nationale du Zaïre). Contribution à l'histoire de l'Université Africaine. Tome II (Paris: L'Harmattan, 2018), 9-84.

In this way, I think, Okolo escapes the bitter judgement of Hountondji: “At a time when the gap between oppressor and oppressed is widening throughout our continent and political differences are becoming more radical, the ethnophilosopher claims that we have always been, still are and always will be unanimous. On every side we see terror tightening its stranglehold on us [...]; every word spoken spells danger and exposes us to untold brutality and may even cost us our lives; insolent neocolonial state apparatuses parade in triumph, leaving a trail of intimidation, arbitrary arrest, torture and legal assassination and poisoning genuine thought at its source. And the official ideologue smiles, content, and declares: 'Alleluia, our ancestors have thought!" African Philosophy: Myth and Reality (Bloomington, IN: Indiana University Press, [1976] 1983), 170.

52 My review of Jörn Rüsen and Henner Laass, eds., Humanism in Intercultural Perspective: Experiences and Expectations (Bielefeld: Transcript, 2009) in Geschichte transnational / History Transnational, http://geschichte-transnational.clio-online.net/rezensionen/, published May 2012, last accessed 5 February 2021 contains an example of how dialogue can be undermined. 53 Compare for instance (on the African side), David Oyedola, "The Culture-oriented Bias of African Philosophical Inquiry,” Filosofia Theoretica 3, no. 2 (2014): 62-80 with Bekele Gutema, 
at any stage assume that the awareness of culturally specific perspectives takes for granted something like pure cultures - I have demonstrated how Okolo speaks from a position of mixture; Ricœur's Symbolism of Evil is a long genealogy of his own cultural heterogeneity. By extension one has to assume that "culture" here includes any form of transmitted symbolism and practice (and not just mainstream tradition).

2. Therefore, initially, at least, neither may speak for the other - each gets the opportunity to advance and develop problems on his/her own terms, on an equal footing. The African philosopher is not summoned merely to respond to the initiative of a Western philosopher, and nor is he/she required to contribute while representing the Western epistemic or political concerns. My paper started from Ricœur, but there is no substantial reason why I could not have started with Okolo, since the need for debate is generated independently from both settings.

3. While recognizing that each thinks from a dissimilar position, we should also note that the similarities due to the globalisation of modernities are not wished away in this debate. Rather, the socio-political conditions of globalisation and the diversified ways that "universal civilization" spreads through different localities ${ }^{54}$ are both at stake in this exchange. These conditions explain why both discussants are able to identify the subjects of discussion in which they are versed; subjects that are relevant to cultural diversity in the absence of hierarchy. At the same time, the table is set for reciprocal critique.

In short, the point of discussing Okolo in the framework of this study on Ricœur was to thematize these conditions for the kind of intercultural confrontation required by disillusioned modernity by means "other than the shock of conquest and domination". ${ }^{55}$ The motivation for participation in such a dialogue arises from an awareness (a prise de conscience, perhaps) that modernisation has globalised a diverse humanity and the artificial cover-up for this situation by means of colonization has fallen away. We have seen Ricœur's picture of this predicament, but Okolo's is not substantially different - he describes this crisis as the "choice between tradition and modernity; conflict between two cultures, African and European; growth crisis of young countries; struggle between the nascent bourgeoisie, backed by capitalist imperialism and exploited proletarians;

“The Intercultural Dimension of African Philosophy," African Study Monographs 36, no. 3 (2015): $139-54$.

54 Cf. Kumar, From Post-industrial to Post-modern Society, 7-16.

55 Ricœur, "Civilisation universelle...," 337 / "Universal Civilization...," 282. 
etc." ${ }^{56}$ Whatever the conditions may have been and still are that ignite this crisis, according to Okolo, this is the motivation for a hermeneutics in response to modernity mode africano demonstrata.

But before we get swept away by this beautiful picture, we have to consider what dialogue means here. When it is applied to personified entities such as "cultures", "dialogue" may refer to any form of exchange that does not, in a lasting way, consist of mere force. In other words, "dialogue" between cultures does not exclude the power dynamics that may include episodic and strategic deployment of forceful means (a fact that I examine in Chapter 2, §4). I say this to emphasise that I do not subscribe to the dream that intercultural conflict can be solved in seminars. At the same time, this is no vision of the inevitable "clash of civilizations" either. I support Mohammed Arkoun's idea that there is no clash between civilizations, only a clash between institutionalized forms of ignorance. ${ }^{57}$ Cultural diversity is not only a threat - quite the contrary: I concur with the spirit of Ricœur's claim when he says: "I am convinced that a progressive lslamic or Hindu world in which old ways of thinking would inspire a new history, would have with our European culture and civilization that specific affinity that all creative people share." ${ }^{58}$ Of this wide, realistic understanding of dialogue, the reconstructed exchange between two philosophers is only one very particular manifestation..$^{59}$ In Chapters 7 and 8 of this book I will attempt to demonstrate some of the broader complexities of the conflict of interpretation in action, as I understand it.

\section{Conclusion: Philosophising at the Edge}

In this chapter I strove to fan the conflict of interpretations over the meaning of the name "Ricœur". Taking his early anti-colonial tract as my point of departure, I traced two lines of development in his thought: first, his geopolitics for the

56 Okolo, Pour une philosophie, 40.

57 E.g. in Mohammed Arkoun, "Clarifier le passé pour construire le futur," Confluences. Méditerranée 16 (1995-1996): 17-30, here 19.

58 Ricœur, “Civilisation universelle...," 337 / "Universal Civilization...,” 283 (citation modified). 59 There are also other kinds of intercultural dialogue possible and are taking place; to give one example: the centuries-old exchanges between mystics. As far as I can see, mystics share with hermeneuticists a willingness to self-relativise, and a refusal of dogmatism and contextualisation. However, I think (like Okolo) that there is an intimate link between hermeneutics, and modernity considered as a crisis. This makes of the point of departure of hermeneutic dialogues something different from mystic exchanges. 
post-independence world and, second, his cultural critical view on modernity, as revealed by decolonization. I highlighted the significance of these two lines of thought for understanding Ricœur's hermeneutics as a response to disillusioned modernity. A major implication of this view on Ricœur's work is that it requires completion by the cultural and geopolitical other. Finally, I reflected on the conditions of such "inter-continental" philosophical debate by taking Okolo Okonda as an exemplary partner. The necessity and feasibility of such a debate both point to the importance of feeding it back into a broader philosophical practice, notably in working on issues such as those of geopolitics and social critique, which I have touched on here.

Altogether, this chapter results in a view on "Ricœur" as the name for a philosophical ethos of letting the fate and views of the others resonate in our own mind, under global conditions of increasing uncertainty and perplexity. Whether this ethos finds expression in intercultural philosophy or just as a commitment to allow others' concerns to bear on our reflection, it nevertheless still requires us to exert maximum critical vigilance (as I have argued in Chapter 1). This is indispensable in the kind of general anthropological exploration of action that I attempt in this book. Accordingly, Chapters 7 and 8 aim, amongst other things, to advance our understanding of the technicity of action from sources other than Western ones.

Given the extremely complex nature of all possible interactions (artistic, commercial, political, military, etc.) between individuals and groups from different backgrounds in general, and the fragility of planned debate aimed at mutual understanding in particular, it would be injudicious to assume that such exchanges tend to lead to mutual understanding and appreciation, or to practically sustainable compromises (on this, see Chapter 2). There are no guarantees, and there are many risks. As far as I can see, the only unquestionable motivation to pursue such a treacherous enterprise and the clearest vanishing point for directing discussions is the constant stream of miserable hordes huddling at the edges of our social life. The ultimate orientation of our scholarly and political endeavours can only be the almost uncountable people who, like the waste of the modern word, are pushed beyond the edge of a meaningful existence into social death. Only an awareness of their fate can generate responses to the sceptical question of nihilism. ${ }^{60}$

60 Coda: "we have adopted their language in turn" ("nous avons tour à tour adopté leurs langages" Okolo, Tradition et destin, 268)

It is on the question of intercultural philosophical dialogue that my discussion ended. But this was still a position taken by a single philosopher - hence, a single contingent perspective. What then is the status of my monologue? 
Is it not fundamental to the intelligibility of my whole chapter to respond to the question of where I stand when I construct this debate? Am I Ricœur's advocate and thereby a campaigner for a Western-dominated stance; is this chapter a slanted exercise of assimilation in the name of Western thought? Or was the whole chapter, from the beginning, arranged to assert a set of African concerns, marked by the figure of Okolo, whose spokesperson I have made myself? Is this nothing but a masked exercise in the revenge of African thought?

This question should at least be mentioned in order to signal its significance. However, since I have no intention of writing an autobiography here, a schematic response will have to suffice. What I have been doing is neither merely exposing myself to the cultural other (Ricœur? Okolo?), nor merely reconstructing a debate between two partners. I am assuming a third possibility, taking on a third position. In this way, I was engaging in a hermeneutics of my situation in this world, by setting up in debate two authors from different contexts from mine, to learn from them both. And through my agreements and disagreements with them, I continued a life of intellectual bastardizing, which is a fate and a chance (cf. Ernst Wolff, "Adam Small's Shade of Black Consciousness," in Philosophy on the Border. Decoloniality and the Shudder of the Origin, ed. Leonard Praeg (Pietermaritzburg: UKZN Press, 2019), 112-47). 